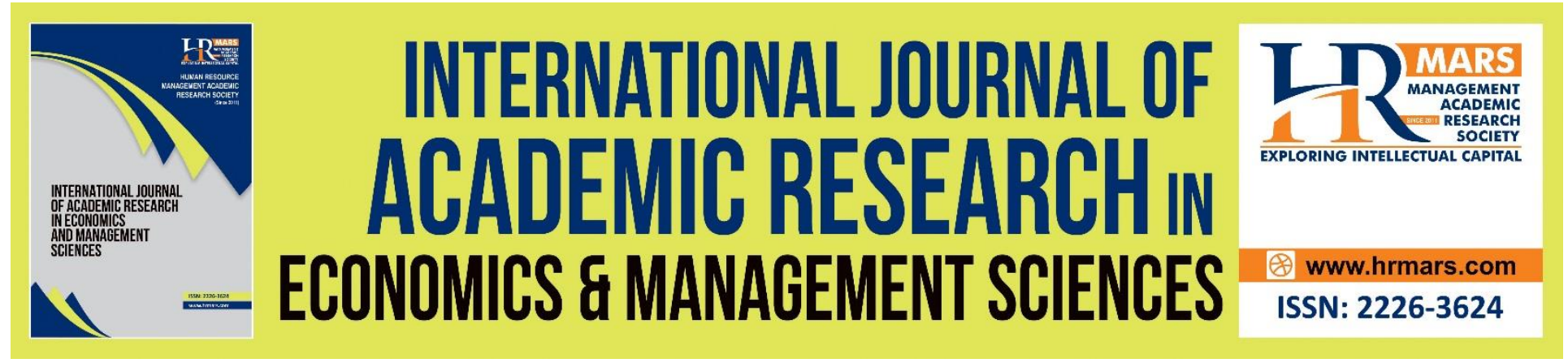

\title{
A Study of Relationship Between Entrepreneurial Barriers and Entrepreneurship Intentions among University Students in Malaysia
}

Noorain Mohd Nordin, Nur Haziqah Russli, Wei-Loon Koe, Zainah Jalil, Nor Aizan Mohamed

To Link this Article: http://dx.doi.org/10.6007/IJAREMS/v10-i3/11370

DOI:10.6007/IJAREMS/v10-i3/11370

Received: 11 July 2021, Revised: 29 July 2021, Accepted: 09 August 2021

Published Online: 05 September 2021

In-Text Citation: (Nordin et al., 2021)

To Cite this Article: Nordin, N. M., Russli, N. H., Koe, W.-L., Jalil, Z., \& Mohamed, N. A. (2021). A Study of Relationship Between Entrepreneurial Barriers and Entrepreneurship Intentions among University Students in Malaysia. International Journal of Academic Research in Economics and Management and Sciences, 10(3), 418-427.

Copyright: (C) 2021 The Author(s)

Published by Human Resource Management Academic Research Society (www.hrmars.com)

This article is published under the Creative Commons Attribution (CC BY 4.0) license. Anyone may reproduce, distribute, translate and create derivative works of this article (for both commercial and non-commercial purposes), subject to full attribution to the original publication and authors. The full terms of this license may be seen at: http://creativecommons.org/licences/by/4.0/legalcode

Vol. 10, No. 3, 2021, Pg. 418 - 427 


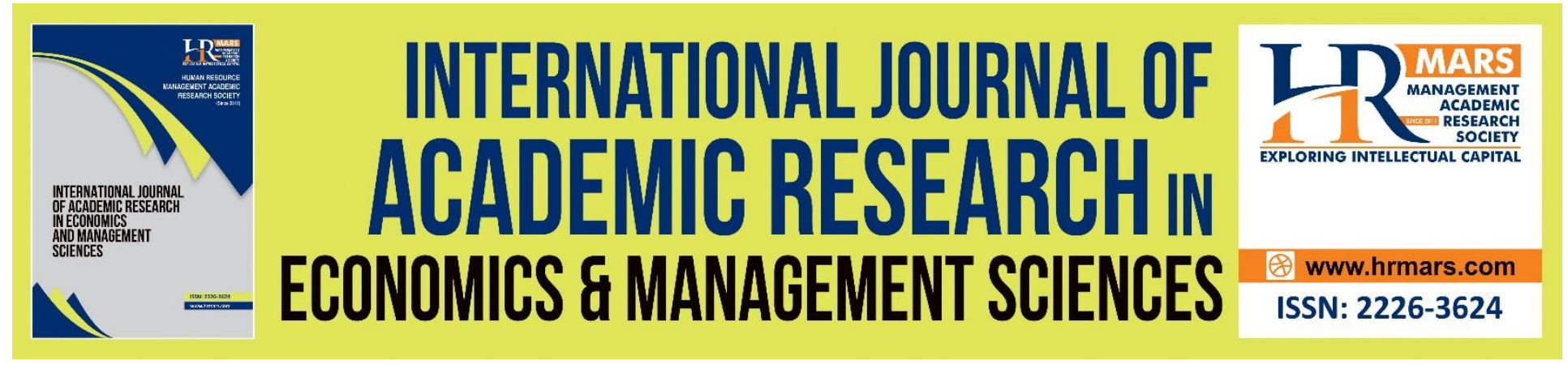

\title{
A Study of Relationship Between Entrepreneurial Barriers and Entrepreneurship Intentions among University Students in Malaysia
}

\author{
Noorain Mohd Nordin, Nur Haziqah Russli, Wei-Loon Koe, Zainah \\ Jalil, Nor Aizan Mohamed
}

Faculty of Business and Management, Universiti Teknologi Mara, Cawangan Melaka

\begin{abstract}
Entrepreneurship is seen as one of the key economic development strategies needed to advance the country's economic growth and to maintain its competitiveness in operating in the growing trend of globalization. Entrepreneurial and entrepreneurial activities play an important role in the economic development of individuals, communities and even countries. Unfortunately, most university students who want to start a business believe that there are many obstacles they have to face in making the business a reality. The purpose of this study is to identify and measure the barriers to entrepreneurship in Malaysia based on one dependent variable and several independent variables. University students face various obstacles such as lack of social networks, lack of resources and fear of failure that can hinder their intention to become entrepreneurs. The barriers faced by university students may indicate a different perspective compared to existing entrepreneurs. This study is quantitative in nature and questionnaires were distributed to collect information from respondents based on 118 sample size measurements and using the convenience sampling method. Data obtained through questionnaires will be analyzed and evaluated with multiple regression statistical tests. The solution of this study aims to fill the research gap and also be able to provide useful insights of youth entrepreneurship to policy makers, education management and government to foster student entrepreneurship develop entrepreneurial ecosystem and improve business environment.
\end{abstract}

Keywords: Entrepreneurship Intentions, Barriers, Social Networking, Resources and Fear of Failure.

\section{Introduction}

This research focuses on entrepreneurial barrier factors. Entrepreneurship has been recognized worldwide in the field of business research (Sandhu et al., 2011). This is one of the factors for achieving job creation and economic development (Gorman et. al., 1997). For both developed and developing countries, it is agreed by researchers, policymakers and academics that entrepreneurship is a critical path to economic progress (Temtime et al., 2004). The key 
instruments for entrepreneurship not only contribute to political, employment, and social stability, but also the competitiveness and innovation by small businesses today especially the new ones (Thurik and Wennekers, 2004).

In Malaysia, activities and concepts are becoming more important for entrepreneurial development. The increase in the number of policies and support mechanisms available to entrepreneurs is one of the proofs of the importance of entrepreneurship to the growth of the Malaysian economy. These include physical infrastructure, business advisory services and financing. The priority given by the government to the development and entrepreneurship of entrepreneurs was highlighted in the Ministry of Entrepreneur Development Malaysia in 1995 by creating a special ministry for entrepreneurs. Changes in the work landscape in Malaysia are also being considered in a timely manner with the establishment of the ministry. In Malaysia, graduate unemployment is becoming a major problem. People more difficult to compete for jobs due to the economic growth is now creating less jobs compare to it used before.

Setting up their own business is one of the solutions to graduate unemployment. According to Fallows and Steven (2000), longevity and permanence are no longer important features in a career journey. As large organizations have changed the nature of career prospects, students are more interested in setting up their own businesses. However, that is not a strong factor that drives students to become entrepreneurs because it is difficult to find a stable job. In order for students to become entrepreneurs, there are many obstacles they face. Therefore, it is important to understand the factors that hinder entrepreneurship and the factors that influence the entrepreneurial propensity among students to reduce graduate unemployment. To increase entrepreneurial activity, understanding these entrepreneurial barriers can help policymakers to formulate strategies to eliminate these entrepreneurial barriers.

Although a large number of studies have been conducted previously on attitudes toward entrepreneurship, the findings have yet to be proven (Kim, 2008). A large amount of research investigates perceptions or attitudes towards barriers and entrepreneurship focuses on developed countries (Sandhu et al., 2011). Only one focused on undergraduate students from this research (Koh, 1996) and the research was not comprehensive as it only covered one university and the research was conducted in developed countries. In Malaysia, only a few studies were found (Ramayah and Harun, 2005) and these only focused on postgraduate students and data were collected at individual universities.

Research on entrepreneurship covered by developing countries is limited. The barriers faced by entrepreneurs from developing countries may be different from those of entrepreneurs in developed countries. This is because more advanced education systems and institutional support in developed countries may be more numerous compared to developing countries and this makes the potential barriers fewer. The 2007 Global Entrepreneurship Monitor report states that the number of early -stage entrepreneurs who venture into full -time business is mostly from developed countries (Bosma et al., 2004). With exceptional Romania and China, Greece, Spain, Slovenia, Italy and Puerto Rico are the countries from developed countries that score more than 80 percent. In this research, Malaysia is not included. Therefore, developing 
countries may have more barriers to entrepreneurship compared to developed countries. Therefore, research on entrepreneurial barriers that influence students 'entrepreneurial intentions needs to be done by providing more information and insights on the barriers faced by students. Thus, the question is, to what extent do entrepreneurial barriers influence entrepreneurial intentions among university students in Malaysia.

\section{Literature Review Entrepreneurial Intentions}

Entrepreneurial intention is described by Thompson (2009) as 'the self-confidence of a person who intends to set up a new business and intends to do so in the future'. According to Ajzen (1991) also, who introduced the Theory of Planned Behavior, intention is determined by social / subjective norms and perceived control of behavior. Social norms are considered to be an individual's perception of his or her behavior that corresponds to the thoughts of significant others, while perceived behavioral control is a network of target behaviors within decision making abilities (Esfandiar et al., 2019). Do and Dadvari (2017) also define entrepreneurial intention as an attentive state of mind that reflects personal experience, awareness and interest in planned entrepreneurial activities.

Longitudinal research by Kautonen et al (2015) confirmed that entrepreneurial intention can predict individual entrepreneurial behavior. Thus, the question of what influences the intentions of the nerves involves policymakers, scholars, and practitioners. Entrepreneurial intention is defined as the self -confidence of an individual who intends to start a new business and plans to do so in the future (Thompson, 2009). Entrepreneurial intentions are either aplan or a desire to create new companies or business activities (Krueger et al., 2000) or start an organization (Popescu et al.,2016). Entrepreneurial intentions and behaviors are closely related (Neneh, 2019). To be more specific, entrepreneurial behavior is the process of searching, evaluation, and exploitation of business opportunities to make new business activities (Shane and Venkataraman, 2000) with entrepre-neurial intentions being the very first and very important step of the whole process.

The focus of entrepreneurship is on entrepreneurial intentions before starting an actual business as it determines the starting point of new business creation. Personal commitment that makes a big impact in creating new ventures comes from the entrepreneurial intentions of Choo and Wong (2006). This intention also describes the behavior and involvement of individuals who are motivated or motivated to start a new venture.

\section{Entrepreneurial Barriers}

Lack of Social Network

Entrepreneurs using social networks are important to start a business in order to get help from a variety of potential sources. Social networks are a major part of social capital to an entrepreneur and also act to increase human capital returns such as education and common sense (Sandhu et al., 2011). Social and human capital show that it affects small business performance because of the importance of discovery -based social networks in many countries including industrial people like Holland (Bosma et al., 2004) and transformational economies like Bulgaria (Manev et al., 2005). 
In China, social networking is an important factor in building long -term business relationships and reducing unforeseen risks (Taormina and Lao, 2007). Social networks may also be very important in the early stages of initiation where internal resources are often very limited (Jones and Jayawarna., 2010). In addition, social networks also influence the early stages of business establishment so that companies can survive to strengthen the quantity and quality of entrepreneurial actions Dodd and Keles (2014). Social networking is a very important factor that will influence entrepreneurial activities for an entrepreneur among students who want to set up their own business, especially in developing countries such as Malaysia.

According to Sorenson and Waguespack (2006), the main challenge of setting up a business is by finding external partners in the cultural sector to maintain a durable sponsorship network. Through social networks as well, entrepreneurs are able to acquire business relationships, information, resources very important for their sustainability and (Neergaard et al., 2005). However, social networks may or may not exist among young entrepreneurs such as students.

\section{Lack of Resources}

A number of people are motivated and motivate them to start a business with the necessary behaviors. Unfortunately, research shows that entrepreneurial availability is an important determinant of the entrepreneurial process. Indian students identify resource scarcity as the most important barrier to entrepreneurship (Giacomin et al., 2011). Some of the important resources that influence the success of startups are the availability of information, access to markets and financial capital. Research by Edward and Chooi (2007) in Malaysia also reported that lack of funds is a barrier faced by small and medium enterprises. Studies involving students show that lack of resources is a barrier to entrepreneurship.

In developing nations, it is difficult to raise funds in starting business as there are only few funding agencies, and venture capitalists and business angels are almost unheard Mason (2008). Meanwhile, according to (Bojica et al., 2018) lack of resources such as capital and economic abilities, financing, a high number of legal requirements, and lack of public assistance is the main factor complicating business start-ups.

Resources are one of the most difficult factors for the growth of entrepreneurial ventures (Ramayah and Harun, 2005). According to (Sandhu et al., 2011). Entrepreneurs who set up their own businesses face barriers to obtaining financing and funds in banking system. In addition, when entrepreneurs were questioned, most of them said that increasing resources was their main problem.

\section{Fear of Failure}

Failure and entrepreneurship go hand in hand but for those who are strong and brave, failure will teach them how to be more successful in the future. Fear of failure is the most common reason why entrepreneurs do not start their own businesses (Bosma et al., 2007). According to Cumming and Johan (2007). the biggest factor why people are afraid to run a business is because they are afraid their business will fail. Unfortunately, this is a fact as we can see, the majority of students tend to work in offices, are instructed to do this and that once they graduate and just wait for their salary at the end of the month. Another research by Henderson and Robertson (1999) at a university in the UK found that students who are not entrepreneurial are afraid of failure. 
Furthermore, some studies show that students are more afraid of risk compared to adult entrepreneurs. According to Neergaard et al (2006), found that gender -specific differences in risk taking were one of the important reason's students did not want to be entrepreneurs where $56 \%$ of women from the sample stated that they were afraid of failing as an excuse so they could avoid setting up their own businesses. In addition, in the cross-culture (Langowitz and Minniti, 2007). study also found that women negatively related to the fear of failure in order to establish their own business.

\section{Research Methodology}

An adapted questionnaire, with some adaptations to suit the context of the study, was used. The data were collected from the sample using the validated and reliable research instrument. After the data were collected, they analysed using multiple regression analysis. Multiple linear regression analysis was used to determine the contributions of each of the significant predictors or independent variables towards the variance in the criterion or dependent variable.

Target populations of this study are the students from selected public universities in Malaysia as the respective respondents. From this statement, 118 respondents have been chosen to represent the total population of the students. For this research, the sampling method that will be use by researcher is convenience sampling under non-probability technique. The research instrument that has been use in this study is questionnaire. The questionnaires that has used in this research study will be classified into five section and other several parts.

First, Section A comprises the demographic background of the respondents. It consists of gender, age, name of university of the respondents. Next, Section B is aimed to examine and evaluate the dependent variable adapted from Abdullateef.et al (2016) on student entrepreneurial intentions. For the independent variable, lack of social networking adapted from Taormina and Lao (2007), while lack of resources (Ramayah and Harun, 2005) and fear of failure by (Scott and Twomey, 2001). The data were analysed using the SPSS reliability and, the Cronbach's Alpha coefficient of reliability was derived. The reliability index Cronbach's Alpha of the entrepreneurial inclination was 0.903 while for independent variables which consist of lack of social network $(0.860)$, lack of resources (0.840), and fear of failure (0.919).

\section{Findings}

As shown in Table 1, the value of $R^{2}=0.404$ this indicates that $40.4 \%$ of the variance determinants of entrepreneurship intentions was influenced by independent variables of this study. Consequently, $59.6 \%$ of the variance to enhance entrepreneurship intentions was explained by other factors. The results shown, lack of social network was the most significant predictor variable that contribute to the entrepreneurship intentions with the value of $(\beta=-0.768)$ or $76.8 \%$ and significant at 0.000 . The significance level for lack of resources also less than $5 \%$ significance level which is 0.000 , means that lack of resources was also significant with the value of $(\beta=-$ $0.550)$ and followed by fear of failure with value of $(\beta=-0.383)$. Therefore, it shows that all independent variables have significant relationship on entrepreneurship intentions. 
Table 1: Regression Analysis Summary

\begin{tabular}{lccc}
\hline Variables & Standardized Coefficient $(\boldsymbol{\beta})$ & Sig. & $\mathbf{R}^{\mathbf{2}}$ \\
\hline & & & \\
(Constant) & & 0.000 & 0.404 \\
Lack of Social Network & -0.768 & 0.000 & \\
Lack of Resources & -0.550 & 0.000 & \\
Fear of Failure & -0.383 & 0.000 & \\
\hline
\end{tabular}

Dependent variable: Entrepreneurial Intention

Lack of social networks is the highest entrepreneurial barrier in this research as students desperately need social networks to motivate them or inspire them in doing entrepreneurial activities. Asian culture really influences entrepreneurial activity because Asians rely heavily on social networks even in business. Asians tend to build good relationships with others even before they embark on an actual goal. Furthermore, students are not exposed with the business world which will be the reason why the students need the suitable social network to bring them in entrepreneurship world.

In addition, lack of resources was also found to be an obstacle to entrepreneurship for students. Past research that has been conducted in developed countries involving students has also found similar results (Manev et al., 2005) and (Bosma et al., 2004). This also happen same as Malaysia which is still a developing country may have a not really proper institutional support especially in term of government or other related agencies in helping entrepreneur compared to more developed nations.

Fear of failure is an important barrier highlighted and it is supported by past studies in the Global Entrepreneurship Monitoring Report 2007 (Bosma et al., 2004) and research conducted for postgraduate students in Malaysia (Sandhu et al., 2011). This may be a more relevant factor for students because the student is in university and they just live between them. This will make them more afraid and not accept the challenge.

\section{Conclusion}

This research has both implications in term of policy and theoretical. The findings of this research supported the literature and the researcher can conclude that those barriers to entrepreneurship faced by universities student from developed country also apply to student from developing country.

Result of this study showed that entrepreneurship barrier significantly affects entrepreneurial intentions. This study investigates into the relationships of the entrepreneurial intentions and all independent variables of the study had provided significant results.

This study clearly shows that entrepreneurial aspirations among university students are high. The mean scores obtained were higher when compared to previous studies that included undergraduate (Lee et al., 2005) and postgraduate students (Sandhu et al., 2011). Therefore, there is a possibility that these educated individuals can be nurtured and developed to become successful entrepreneurs. They will advance in realizing the government's vision by promoting entrepreneurship among our citizens. Unfortunately, just having high entrepreneurial intentions 
is not enough because intentions and desires need to be turned into action. Therefore, the government needs to remove and prevent all personal or psychological barriers that prevent students from becoming entrepreneurs.

In addition, educational institutions also need to provide exposure to students about real entrepreneurs so that they can have a good social network. Students will be more interested and be able to be closer to the entrepreneur and be able to overcome all obstacles. It is also to increase funding and social networking the government needs to ensure adequate funds are allocated for new entrepreneurs and create mechanisms to increase social networking among industry players and for investors. It is important for governments and universities to understand how to develop and nurture potential entrepreneurs even if they are still students. This study should also be extended in the future to include students from other universities in Asian countries so as to provide stronger evidence on the application of the findings in an evolving context. It would also be interesting to conduct an extensive in-depth research using a qualitative approach on the different variables.

\section{Acknowledgement}

The author would like to thank the Universiti Teknologi Mara Cawangan Melaka and co-authors that have helped in conducting and completing this research. This research has funded by Grant Teja (GDT2021/1-2).

\section{Corresponding Author}

Noorain Mohd Nordin

Universiti Teknologi Mara, Cawangan Melaka, Malaysia

Email: noorainnordin01@gmail.com

\section{References}

Abdullateef, B. N., Elias, N. F., Mohamed, H., Zaidan, A. A., \& Zaidan, B. B. (2016). An evaluation and selection problems of OSS-LMS packages. SpringerPlus, 5(1), 1-35.

Ajzen, I. (2011). The theory of planned behaviour: Reactions and reflections: 1113-1127

Bojica, A. M., Ruiz Jiménez, J. M., Ruiz Nava, J. A., \& Fuentes-Fuentes, M. M. (2018). Bricolage and growth in social entrepreneurship organisations. Entrepreneurship \& Regional Development, 30(3-4), 362-389.

Bosma, N., Van Praag, M., Thurik, R. and De Wit, G. (2004), "The value of human and social capital investments for the business performance of start-ups", Small Business Economics, Vol. 23 No. 3, pp. 227-41.

Cumming, D., \& binti Johan, S. A. (2007). Advice and monitoring in venture finance. Financial Markets and Portfolio Management, 21(1), 3-43.

Choo, S., \& Wong, M. (2006). Entrepreneurial intention: triggers and barriers to new venture creations in Singapore. Singapore management review, 28(2), 47-64.

Dodd, S. D., \& Keles, J. (2014). Expanding the networks of disadvantaged entrepreneurs. OECD Centre for Entrepreneurship, SMEs and Local Development.

Do, B. R., \& Dadvari, A. (2017). The influence of the dark triad on the relationship between entrepreneurial attitude orientation and entrepreneurial intention: A study among 
INTERNATIONAL JOURNAL OF ACADEMIC RESEARCH ECONOMICS AND MANAGEMENT SCIENCES

Vol. 10 , No. 3, 2020, E-ISSN: 2226-3624 ㄷ 2020 HRMARS

students in Taiwan University. Asia Pacific Management Review, 22(4), 185-191.

Edward, R. C., \& Chooi, L. W. (2007). Malaysia vs. Singapore; e-commerce supremacy in Asia. Part, 2, 259-73.

Esfandiar, K., Sharifi-Tehrani, M., Pratt, S., \& Altinay, L. (2019). Understanding entrepreneurial intentions: A developed integrated structural model approach. Journal of Business Research, 94, 172-182.

Fallows, S., \& Steven, C. (2000). Building employability skills into the higher education curriculum: a university-wide initiative. Education+ training.

Giacomin, O., Janssen, F., Pruett, M., Shinnar, R. S., Llopis, F., \& Toney, B. (2011). Entrepreneurial intentions, motivations and barriers: Differences among American, Asian and European students. International Entrepreneurship and Management Journal, 7(2), 219-238.

Henderson, R., \& Robertson, M. (1999). Who wants to be an entrepreneur? Young adult attitudes to entrepreneurship as a career. Education+ Training.

Jones, O., \& Jayawarna, D. (2010). Resourcing new businesses: social networks, bootstrapping and firm performance. Venture Capital, 12(2), 127-152.

Kautonen, T., Van Gelderen, M., Fink, M. (2015) Robustness of the Theory of Planned Behaviour in Predicting Entrepreneurial Intentions and actions. Enterpren Theory Pract. 39 (3), 655674.

Kim, G. (2008), "Entrepreneurship and self-employment: the state-of-the-art and directions for future research", New England Journal of Entrepreneurship, Vol.11 No. 1, pp. 39-52.

Krueger, Jr. N. F., Reilly, M. D., \& Carsrud, A. L. (2000). Competing models of entrepreneurial intentions. Journal of business venturing, 15(5-6), 411-432.

Lee, S. M., Chang, D., \& Lim, S. B. (2005). Impact of entrepreneurship education: A comparative study of the US and Korea. The international entrepreneurship and management journal, 1(1), 27-43.

Langowitz, N., \& Minniti, M. (2007). The entrepreneurial propensity of women. Entrepreneurship theory and practice, 31(3), 341-364.

Manev, I. M., Gyoshev, B. S., \& Manolova, T. S. (2005). The role of human and social capital and entrepreneurial orientation for small business performance in a transitional economy. International journal of entrepreneurship and innovation management, 5(3-4), 298-318.

Mason, C. M. (2008). The real venture capitalists: a review of research on business angels. Hunter Center for Entrepreneurship, 1-55.

Neergaard, H., Shaw, E., \& Carter, S. (2005). The impact of gender, social capital and networks on business ownership: a research agenda. International Journal of Entrepreneurial Behavior \& Research.

Neneh, B. N. (2019). From entrepreneurial intentions to behavior: The role of anticipated regret and proactive personality. Journal of Vocational Behavior, 112, 311-324.

Popescu, C. C., Bostan, I., Robu, I. B., \& Maxim, A. (2016). An analysis of the determinants of entrepreneurial intentions among students: a Romanian case study. Sustainability, 8(8), 771.

Ramayah, T., \& Harun, Z. (2005). Entrepreneurial intention among the student of Universiti Sains Malaysia (USM). International Journal of Management and entrepreneurship, 1(1), 8-20.

Sandhu, M. S., Sidique, S. F., \& Riaz, S. (2011). Entrepreneurship barriers and entrepreneurial 
INTERNATIONAL JOURNAL OF ACADEMIC RESEARCH ECONOMICS AND MANAGEMENT SCIENCES

Vol. 10 , No. 3, 2020, E-ISSN: 2226-3624 ㄷ 2020 HRMARS

inclination among Malaysian postgraduate students. International journal of entrepreneurial behavior \& research.

Scott, M. G., \& Twomey, D. F. (1988). The long-term supply of entrepreneurs: students' career aspirations in relation to entrepreneurship. Journal of small business management, 26(4), 5.

Shane, S., \& Venkataraman, S. (2000). The promise of entrepreneurship as a field of research. Academy of management review, 25(1), 217-226.

Sorenson, O., \& Waguespack, D. M. (2006). Social structure and exchange: Self-confirming dynamics in Hollywood. Administrative Science Quarterly, 51(4), 560-589.

Taormina, R. J., \& Lao, S. K. M. (2007). Measuring Chinese entrepreneurial motivation: Personality and environmental influences. International Journal of Entrepreneurial Behavior \& Research.

Temtime, Z. T., Chinyoka, S. V., \& Shunda, J. P. W. (2004). A decision tree approach for integrating small business assistance schemes. Journal of Management Development.

Thompson, E. R. (2009). Individual entrepreneurial intent: Construct clarification and development of an internationally reliable metric. Entrepreneurship theory and practice, 33(3), 669-694.

Thurik, R., \& Wennekers, S. (2004). Entrepreneurship, small business and economic growth. Journal of small business and enterprise development. 